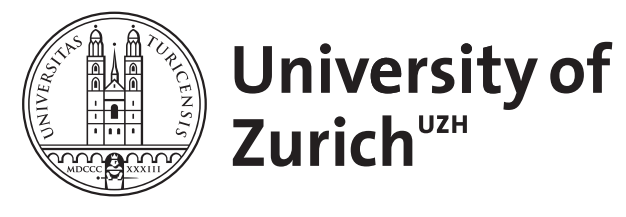

\title{
Legislation in Switzerland
}

Höfler, Stefan ; Nussbaumer, Markus ; Uhlmann, Felix

\begin{abstract}
Switzerland has a multi-lingual, multi-layered civil law system. Its current legal system was established in 1848, when the modern Swiss state was founded, and has been further developed since then. Swiss legislation has come to be shaped by three basic constitutional tenets: federalism, direct democracy and separation of powers. Individually and together, these tenets have created unique political necessities and legislative traditions.
\end{abstract}

Posted at the Zurich Open Repository and Archive, University of Zurich ZORA URL: https://doi.org/10.5167/uzh-193277

Book Section

Published Version

Originally published at:

Höfler, Stefan; Nussbaumer, Markus; Uhlmann, Felix (2020). Legislation in Switzerland. In: Karpen, Ulrich; Xanthaki, Helen. Legislation in Europe: A Country by Country Guide. Oxford: Hart Publishing, 481-496. 


\title{
30
}

\section{Legislation in Switzerland}

\author{
STEFAN HÖFLER, MARKUS NUSSBAUMER AND FELIX UHLMANN
}

\section{Context}

Switzerland has a multi-lingual, multi-layered civil law system. Its current legal system was established in 1848, when the modern Swiss state was founded, and has been further developed since then. Swiss legislation has come to be shaped by three basic constitutional tenets: federalism, direct democracy and separation of powers. ${ }^{1}$ Individually and together, these tenets have created unique political necessities and legislative traditions.

\subsection{Layers}

Swiss legislation is layered hierarchically into federal, cantonal and communal law, each of which is in turn layered into a constitution, primary legislation (acts of Parliament) and secondary legislation (ordinances). This layering reflects the roles that (a) the different levels of government (the confederation, cantons and communes), (b) the people and (c) the three branches of government (the legislature, executive and judiciary) play in Swiss legislation.

\subsubsection{The Confederation, Cantons and Communes}

Switzerland is a federal state. Article 1 of its Constitution ${ }^{2}$ stipulates that the Swiss Confederation is formed by 'the People and the Cantons.' ${ }^{3}$ In 1848, Switzerland turned from a loose confederation into a federal state. Nevertheless, the cantons have retained a strong

\footnotetext{
${ }^{1} c f$ P Egli, Introduction to Swiss Constitutional Law (Zurich, Dike, 2013); W Haller, The Swiss Constitution in a Comparative Context, 2nd edn (Zurich, Dike, 2016); A Misic and N Töpperwien, Constitutional Law in Switzerland, 2nd edn (Bern, Stämpfli, 2018); M Thommen (ed), Introduction to Swiss Law (Berlin, Carl Grossmann, 2018).

${ }^{2}$ Federal Constitution of the Swiss Confederation of 18 April 1999 (SR 101).

${ }^{3}$ The Swiss Confederation consists of 26 cantons: Zurich, Bern, Lucerne, Uri, Schwyz, Obwalden and Nidwalden, Glarus, Zug, Fribourg, Solothurn, Basel-Stadt and Basel-Landschaft, Schaffhausen, Appenzell Ausserrhoden and Appenzell Innerrhoden, St Gallen, Graubünden, Aargau, Thurgau, Ticino, Vaud, Valais, Neuchâtel, Geneva and Jura.
} 
position within Switzerland's constitutional framework: they are 'sovereign except to the extent that their sovereignty is limited by the Federal Constitution' and they 'exercise all rights that are not vested in the Confederation' (Article 3 of the Federal Constitution). The Confederation is obliged to 'leave the Cantons sufficient tasks of their own and respect their organisational autonomy' (Article 47, para 2 of the Federal Constitution). The cantons, in turn, 'shall implement federal law in accordance with the Federal Constitution and federal legislation' (Article 46, para 1 of the Federal Constitution). The Confederation typically legislates on issues such as foreign relations, defence, the economy, civil and criminal law (and recently also procedural law), nuclear energy, telecommunications and social security, while the cantons remain responsible for issues such as education, religion and police, health and social benefits. The Confederation and the cantons are jointly responsible for legislation in areas such as public transport, road infrastructure and the environment ( $c f$ Articles 54-135 of the Federal Constitution). Where there is joint responsibility, the Confederation may typically enact the general legal framework, but may leave it to the cantons to implement it and refine the details.

To achieve greater harmonisation in Swiss law, the Confederation increasingly interferes with areas that have traditionally been the sole responsibility of the cantons ( $c f$, eg, Article $61 a$ of the Federal Constitution with regard to education). However, the cantons may also strive for such harmonisation themselves, namely by entering into agreements with each other and establishing common organisations and institutions (Article 48 of the Federal Constitution). Thus, they create an intermediate level of government located somewhere between the level of the Confederation and the level of the individual cantons. ${ }^{4}$

Beneath the cantons, there is yet another level of government: the communes. The Federal Constitution guarantees the autonomy of the communes in accordance with cantonal law' (Article 50, para 1). The Swiss communes are legal entities in their own right and are equipped with their own legislature in the form of a communal parliament or town hall meetings. They may enact their own laws to the extent that they are authorised to do so by cantonal law.

This fourfold division of competence between the Confederation, the inter-cantonal institutions, the cantons and the communes leads to a multi-layered legal system, where, in many cases, legal sources from all levels of government will have to be considered when a specific legal question needs to be resolved. ${ }^{5}$ Such a system creates specific challenges for legislative drafting: it is crucial that any new laws accurately implement all relevant higher-level legislation and that they are themselves amenable to implementation at the next lower level of government. At the same time, it also creates opportunities: the cantons and the communes effectively serve as 'legislative laboratories' where different approaches to common problems may be implemented and compared. ${ }^{6}$

\footnotetext{
${ }^{4} c f$ Egli (n 1) 51-52; Haller (n 1) 87-91; Misic and Töpperwien (n 1) 157-59.

${ }^{5}$ In addition, international law (issued by organisations such as the United Nations (UN), the Organisation for Economic Co-operation and Development (OECD), the World Trade Organization (WTO) and particularly the $\mathrm{EU}$ ) has recently increased both in terms of reach and volume. It has effectively come to form a very substantial fifth level of government, although one over which Switzerland has only very limited influence ( $c f$ section 30.3.3).

${ }^{6}$ For the qualitative differences in cantonal legislation, see F Uhlmann, 'Wer hat und wer macht wie viel? Rechtsbestand und Rechtsetzungsaktivität in den Schweizer Kantonen' (2017) 2 LeGes 371.
} 


\subsubsection{The People}

Switzerland's Federal Constitution provides three major instruments through which the people can participate in legislation: consultation, referendum and popular initiative. Similar means of participation exist at the cantonal and communal levels of government. ${ }^{7}$ Of these three instruments, consultation is the weakest: 'The Cantons, the political parties and interested groups shall be invited to express their views when preparing important legislation or other projects of substantial impact as well as in relation to significant international treaties' (Article 147 of the Federal Constitution). In other words, the government is obliged to ask the public for their opinions, but it is not bound by these opinions.

A stronger instrument is provided by the referendum, which, depending on the issue, is either mandatory or optional. Under the mandatory referendum, amendments to the Federal Constitution and accessions to organisations for collective security or to supranational communities must be put to the vote of the people and the cantons, ie, they need to be approved both by the people of Switzerland as a whole and by a majority of the people of its 26 cantons (Article 140 of the Federal Constitution). Under the optional referendum, any federal act, certain federal decrees and all important international treaties must be submitted to a vote by the people (but not the cantons) if any 50,000 persons eligible to vote or any eight cantons request it within 100 days of the official publication (Article 141 of the Federal Constitution). The referendum thus equips the people with the power to veto legislation if they do not agree with it.

Finally, the strongest means of participation is provided by the instrument of the popular initiative: any 100,000 persons eligible to vote may request an amendment of the Federal Constitution, which must be put to the vote of the people and the cantons (Article 139 of the Federal Constitution). Thus, the people not only comment and decide on legislation, but they may also initiate and draft it ( $c f$ section 30.2.1). However, this last instrument is limited to constitutional amendments, which is one of the reasons why the Swiss Constitution occasionally contains provisions that from the perspective of legislative theory would rather belong in an act of parliament or even just an ordinance.

The fact that the Swiss people have the right to be consulted, to veto and even to initiate legislation has had a substantial impact on its political institutions as well as its legislative process and techniques. Among other things, it has forced all major political parties to work together, as any one of them would easily be able to block a legislative project by means of a referendum or jeopardise a legislative programme through popular initiatives. As a result, Switzerland has gradually evolved into a consensus democracy where all major political forces are integrated into the government. Naturally, the need to reach consensus and participation of the people also slows down the legislative process: in Switzerland, it typically takes several years to get from the initiation of a legislative project to the enactment of a new law. However, this slowness has the advantage that the result is usually broadly accepted. Finally, the fact that a bill will have to pass the test before the people creates a strong incentive to make sure that the people will actually be able to understand what it says;

\footnotetext{
${ }^{7} c f$ Haller (n 1) 236-41, 244-45; Misic and Töpperwien (n 1) 58-59, 75-85. For participation in general, see F Uhlmann and C Konrath, 'Participiation' in U Karpen and H Xanthaki (eds), Legislation in Europe: A Comprehensive Guide for Scholars and Practitioners (Oxford, Hart Publishing, 2017) 73-95.
} 
it is thus one of the reasons why Switzerland has developed a strong tradition of drafting its laws in plain language.

\subsubsection{Legislature, Executive and Judiciary}

The Swiss Parliament, the Federal Assembly, consists of two chambers: a house of representatives, the National Council, and a senate, the Council of States. The National Council is composed of 200 representatives of the people. The representatives are elected directly by the people according to a system of proportional representation, with a general election being held every four years. Each canton constitutes an electoral constituency. The seats are allocated to the cantons according to their relative populations. The Council of States is composed of 46 representatives of the cantons. ${ }^{8}$ The cantons are free to determine the rules for the election of their representatives to the Council of States. Currently, all cantons elect their representatives by popular vote. Thus, the members of the Swiss Council of States are not emissaries of the cantonal governments like the members of the German Bundesrat; ${ }^{9}$ rather, they represent their cantons in the way that US senators represent their states. In contrast to the US Congress, after which they were originally modelled, the two chambers of the Swiss Federal Assembly have exactly the same rights and duties. In particular, any bill must gain the approval of both chambers in order to be enacted. Together with the instruments of direct democracy, this equality of the two chambers of the Swiss Parliament is one of the main reasons why, in comparison to other countries, Switzerland's legislative process is relatively slow.

The Swiss executive, the Federal Council, is a college of seven equal members. The members of the Federal Council are elected individually by the Federal Assembly following each general election to the National Council. The President of the Confederation is chosen annually from among the members of the Federal Council. However, the position is mostly ceremonial; there is no head of government and no individual head of state. By convention, all major political parties are represented in the Federal Council, without there being a 'grand coalition' in the proper sense of the word. There is no coalition agreement between the parties and thus the government can also not 'fall apart'.

The Federal Council is relatively independent of parliament. In contrast to, for example, Germany or the UK, the members of the Swiss executive cannot be Members of Parliament at the same time; like the US, Switzerland has adopted a strict interpretation of the separation of powers. By convention, Federal Councillors are re-elected for however long they decide to stay in office. ${ }^{10}$ Once elected, they cannot be removed from office for the duration of their term: Switzerland's Constitution does not provide for a vote of no confidence. Moreover, the failure of a bill before Parliament or in a referendum does not threaten the stability of the government: the Swiss executive does not usually (and indeed does not have

\footnotetext{
${ }^{8}$ For historical reasons, the cantons of Obwalden, Nidwalden, Basel-Stadt, Basel-Landschaft, Appenzell Ausserrhoden and Appenzell Innerrhoden each elect one representative and all other cantons two ( $c f$ art 150, para of the 2 Federal Constitution).

${ }^{9} \mathrm{cfch} 12$ in this volume.

${ }^{10}$ Since its foundation in 1848 , only four (out of 119) members of the Federal Council have not been re-elected.
} 
to) resign over a lost vote. In turn, this also means that Parliament is relatively independent of the executive. The Federal Assembly interferes heavily in legislative projects presented to it by the executive ( $c f$ section 30.2.3).

The Swiss judiciary, headed by the Federal Supreme Court, may only provide very limited constitutional review. Article 190 of the Federal Constitution stipulates that ' $t$ the Federal Supreme Court and the other judicial authorities apply the federal acts and international law. Thus, the Federal Supreme Court is obliged to apply federal acts even if it deems them unconstitutional. The rationale behind this provision is to be found in the aforementioned instruments of direct democracy. Because there is always the option of a referendum, federal acts come with the explicit or tacit consent of the people. Article 190 of the Federal Constitution prevents the supposedly paradoxical situation whereby a court, on constitutional grounds, rescinds a federal act that the people, ie, the very source of the Constitution, considered to be in keeping with that Constitution. To date, all attempts - both parliamentary and by means of popular initiative - to change or abolish this article have failed. ${ }^{11}$ As a consequence, constitutional review only extends to secondary federal legislation and to cantonal law - and, as strange as it seems, even these must be upheld if their alleged unconstitutionality originates from a federal act or international law. ${ }^{12}$

The limited constitutional review qualifies the role of the Constitution as the defining framework for legislation. The Constitution defines the key elements of the legislative process. It is also due to the Constitution that Parliament is occasionally obliged to pass laws against its own will, namely when it must implement constitutional amendments originating from popular initiatives that it had rejected. Still, the Swiss Parliament is relatively free in terms of how to approach a legislative problem. Whereas in Germany, the Constitutional Court has struck down acts of Parliament, eg, for lack of sufficient gathering of facts, Swiss federal acts are beyond such control, and the Swiss Federal Supreme Court is also rather lenient on the cantons in this regard. Effectively, it is Parliament that has the last say on the constitutionality of its own acts. However, such power is not only a privilege but also a burden. It may help explain certain elements of the legislative process, such as the preliminary constitutional review of all bills during the drafting process. One may even contend that Article 190 of the Federal Constitution has fostered a tradition of diligent law-making, where the preparatory work carried out by the administration is intended to compensate for the lack of an ex post facto constitutional review by the courts. ${ }^{13}$

\subsection{Process}

Depending on the tier of legislation involved (Constitution, act of parliament or ordinance), the Swiss legislative process consists of up to five phases: (a) initiation; (b) drafting; (c) parliamentary deliberation; (d) referendum, commencement and publication; and

\footnotetext{
${ }^{11} c f$ Y Hangartner and ME Looser, 'Art. 190' in B Ehrenzeller, B Schindler, RJ Schweizer and KA Vallender (eds), Die schweizerische Bundesverfassung: St. Galler Kommentar, 3rd edn (Zurich, Schulthess, 2013) 3049-50.

${ }^{12}$ However, the Federal Supreme Court may scrutinise federal legislation under the European Convention on Human Rights (ECHR), which has led - at least in part - to some kind of 'substitute' constitutional review.

${ }^{13} c f$ Federal Council Dispatch of 5 March 2010 on Strengthening Preventive Constitutional Review (BBl 2010 2187), available at: www.admin.ch/opc/de/federal-gazette/2010/2187.pdf.
} 
(e) evaluation. ${ }^{14}$ In what follows, we describe the legislative process of the Confederation; similar processes apply at the cantonal and communal levels of government.

\subsubsection{Initiation}

Constitutional amendments may be introduced by way of legislation or by means of a popular initiative. In the former case, the process is the same as for federal acts (see below), except for the fact that constitutional amendments are subject to a mandatory rather than an optional referendum. In the latter case, any 100,000 persons eligible to vote may request that the Constitution be amended; the respective signatures must be collected within 18 months of the official publication of the initiative. In theory, popular initiatives may either take the form of a specific bill or of a general proposal to be turned into a specific bill by Parliament (Article 139 of the Federal Constitution). In practice, almost all popular initiatives are submitted in the form of a specific bill. Initiators are usually suspicious of Parliament and prefer to retain control over the content of their proposal.

Popular initiatives must comply with the requirements of consistency of form, and of subject matter, and must not infringe upon any mandatory provisions of international law. The Federal Assembly must declare an initiative to be invalid in whole or in part if it fails to meet these requirements (Article 139, para 3 of the Federal Constitution). Apart from such invalidation, neither Parliament nor any other authority may change the text of a popular initiative once it has been submitted, not even the initiators themselves. Thus, the text of the constitutional amendment is final even before the first signature has been collected and the political discussion has begun.

The Federal Assembly may decide to draft a counter-proposal to be put to the vote together with a popular initiative. In the referendum, the people may vote in favour of both proposals; in response to the third question, they may indicate the proposal that they prefer if both are accepted (Article $139 b$ of the Federal Constitution). Like all constitutional amendments initiated by Parliament, counter-proposals are prepared by way of legislation. Alternatively, the Federal Assembly may prepare an indirect counter-proposal in the form of a federal act rather than a constitutional amendment. In this case, the initiators may withdraw their popular initiative under the express condition that the indirect counter-proposal is not rejected in a referendum (Article $73 a$, para 2 of the Political Rights Act). ${ }^{15}$

The preparation of federal acts may be initiated by the Federal Council, by Parliament or by a canton. It may be triggered, among other things, by the need to implement a newly adopted constitutional amendment. The Federal Council has a general right to draft bills and submit them to Parliament (Article 181 of the Federal Constitution). Most legislative projects are initiated in this way. However, bills may also be prepared and introduced by a parliamentary committee (a so-called parliamentary initiative). This option has recently gained traction, with Parliament increasingly trying to curtail the influence of the Federal Council. In addition, any Member of Parliament, any parliamentary group and any canton may propose that parliament pass legislation on a certain matter. If the Federal Assembly

${ }^{14}$ cf M Thommen, 'Swiss Legal System' in Thommen (n 1) 27-30.

${ }^{15}$ Federal Act on Political Rights of 17 December 1976 (SR 161.1). 
agrees, it tasks the Federal Council (in the case of parliamentary motions) or a parliamentary committee (in the cases of parliamentary and cantonal initiatives) with drafting a bill.

The executive issues ordinances where a federal act requires further implementation and where the legislature has delegated the right to legislate on a minor issue to the executive ( $c f$ Articles 164 and 182 of the Federal Constitution). Ordinances may be issued by the Federal Council, a Federal Department (ministry), a Federal Office or another government agency provided they have the authority to do so under the Constitution or the law. The drafting of ordinances follows the same procedure as the drafting of federal acts, but in contrast to federal acts, ordinances are not submitted to Parliament and they are not subject to a referendum. However, there is an ongoing debate as to whether Parliament should be given more influence over the content of ordinances, eg, whether it should be equipped with a right to veto them. ${ }^{16}$ Even under current law, the Federal Council is already obliged to provide an explanation if it submits a bill to Parliament that delegates legislative powers to the executive, and Parliament may request draft ordinances in order to assess the consequences of such delegations.

\subsubsection{Drafting}

Swiss federal legislation is usually drafted by the administration. Even if a bill is formally prepared by a parliamentary committee, the administration is usually tasked with the actual drafting of the text. The drafting phase of the legislative process falls into three stages: (a) the preparation of a preliminary draft; (b) the consultation of the public; and (c) the preparation of a final draft.

\subsubsection{Preliminary Draft}

New legislation is conceptualised and composed in the government office responsible for the policy area concerned. Switzerland has adopted a de-centralised model of legislative drafting, ie, the drafts are prepared not by specialised legislative drafters, but by domain experts familiar with the subject matter at hand. There are pros and cons to such a model:

The advantage of a model where drafting is a general, decentralised function is that it facilitates the exchange of information between those in charge of drafting the law and those applying it. Domain knowledge and practical experience can easily be accessed at all stages of the drafting process. As domain specialists are in charge of drafting, special emphasis is given to the applicability of the new legislation and its compatibility with current practice. The main disadvantage is that domain specialists are usually less familiar with the techniques of formal legistics and the principles of plain-language writing than professional drafters. They are also more prone to getting tangled up in matters of policy; as a result, general legal constraints may be neglected and the authors may fail to adopt the perspective of the target audience and thus infringe on the clarity of the law. ${ }^{17}$

To remedy some of the disadvantages of the model, the office in charge of a draft is obliged to invite all other offices of government that may have an interest in the legislative project to

\footnotetext{
${ }^{16}$ cf G Müller and F Uhlmann, Elemente einer Rechtssetzungslehre, 3rd edn (Zurich, Schulthess, 2013) 270-74.

${ }^{17}$ S Höfler, M Nussbaumer and H Xanthaki, 'Legislative Drafting' in Karpen and Xanthaki (n 7) 153.
} 
comment on it (the so-called 'consultation of offices'). ${ }^{18}$ In the course of this internal review, the draft is also examined by three centralised institutions: (a) the Federal Office of Justice checks if the draft complies with the Constitution and international law; ${ }^{19}$ (b) the Internal Drafting Committee, an inter-disciplinary body made up of language specialists and legal experts, ensures that the language used in the draft is clear and comprehensible; ${ }^{20}$ and (c) the Federal Chancellery checks if the draft adheres to the rules of formal legistics. ${ }^{21}$ These three institutions bring specialised knowledge to the drafting process: knowledge about constitutional constraints, about plain-language drafting and about the formal requirements that federal laws must fulfil.

\subsubsection{Public Consultation}

All preliminary drafts of constitutional amendments, federal acts and important ordinances (as well as important international treaties) must then be released for public consultation (Article 147 of the Federal Constitution). This procedure has 'the aim of allowing the Cantons, political parties and interested groups to participate in the shaping of opinion and the decision-making process of the Confederation. It is intended to provide information on material accuracy, feasibility of implementation and public acceptance of a federal project' (Article 2 Consultation Procedure Act). ${ }^{22}$ In theory, everyone can participate in this process. In practice, the instrument is mainly used by political parties, special interest groups and, crucially, the cantons. Remarks may be submitted for a period of three months. The administration analyses the responses and summarises them in a report. ${ }^{23}$

The feedback provided by the participants of a public consultation has no binding effect. The purpose of a public consultation is merely to test the political feasibility of a legislative project. It enhances the transparency of the legislative process at an early but important stage. The information gathered adds to the fact-finding and practicability assessment of the project. If both the cantons as well as private organisations state that the draft bill would be difficult to implement or would cause unnecessary administrative burdens, such remarks are usually taken seriously. Still, public consultation does not produce scientific evidence: it is neither an expert opinion nor a poll. Participation in a public consultation may be distributed rather asymmetrically: the opinion of certain lobbying groups in particular may be over-represented in the responses returned to the administration. This needs to be taken

\footnotetext{
${ }^{18} c f$ ibid $157 \mathrm{f}$.

${ }^{19} \mathrm{cf}$ Federal Council Dispatch on Strengthening Preventive Constitutional Review (n 13).

${ }^{20}$ cf M Nussbaumer, 'Der Verständlichkeit eine Anwältin! Die Redaktionskommission der schweizersichen Bundesverwaltung und ihre Arbeit an der Gesetzessprache' in KM Eichhoff-Cyrus and G Antos (eds), Verständlichkeit als Bürgerrecht? Die Rechts- und Verwaltungssprache in der öffentlichen Diskussion (Mannheim, Duden, 2008) 230-43; S Höfler, 'Gute Gesetzessprache aus dem Blickwinkel der Verwaltung: Die Redaktionskommission der schweizerischen Bundesverwaltung' in F Uhlmann and S Höfler (eds.), Gute Gesetzessprache als Herausforderung für die Rechtsetzung (Zurich, Dike, 2018) 65-100.

${ }^{21} c f$ T Sägesser, 'Gesetzgebung und begleitende Rechtsetzung: Zuständigkeitsabgrenzung zwischen Bundeskanzlei und Bundesamt für Justiz' (2008) 7 AJP 901; Schweizerische Bundeskanzlei, Gesetzestechnische Richtlinien (Bern, 2013), available online (in German, French and Italian) at: www.bk.admin.ch > Dokumentation > Rechtsetzungsbegleitung > Gesetzestechnische Richtlinien (GTR).

${ }^{22}$ Consultation Procedure Act of 18 March 2005 (SR 172.061).

${ }^{23}$ All planned, running and completed consultations can be inspected online (in German, French and Italian) at: www.admin.ch $>$ Bundesrecht $>$ Vernehmlassungen.
} 
into consideration when the results are analysed. In general, the more seriously respondents are taken, the more capable they are to defeat a project in a referendum.

\subsubsection{Final Draft}

The analysis of the comments from the public consultation lead to revision of the draft (or its abandonment). During this process of consolidation, a second round of internal review (consultation of offices) is carried out and the draft is examined once again with regard to its constitutionality, clarity and adherence to the rules of formal legistics. After this second round of internal review, the draft is finalised and submitted for approval to the Federal Council, the parliamentary committee or, in the case of subordinate ordinances, the Federal Department, Federal Office or other government agency in charge.

For ordinances, this is the end of the legislative process - they are enacted and published, whereas drafts of constitutional amendments and federal acts are now forwarded to Parliament. With this aim in mind, they are attached to an official dispatch or report in which the Federal Council or the parliamentary committee, respectively, explains its motivations for the respective piece of legislation, summarises the results of the public consultation, details the content of the individual provisions contained in the draft, shows that the bill complies with the Constitution and international law, and points to the likely impact the new piece of legislation will have on the cantons, the communes, the economy, the environment and society at large (Article 141 of the Parliament Act). ${ }^{24}$ The Federal Council dispatches and committee reports are important auxiliary texts that the courts may resort to if the interpretation of a provision in the respective federal act is unclear. They are published in the Federal Gazette ${ }^{25}$ and they are explicitly mentioned in the preamble of federal acts. The preamble of the aforementioned Consultation Procedure Act, for example, reads as follows: 'The Federal Assembly of the Swiss Confederation, based on Article 147 of the Federal Constitution, and having considered the Federal Council Dispatch of 21 January 2004, decrees: ...26

\subsubsection{Parliamentary Deliberation}

Decisions of the Federal Assembly require the agreement of both chambers (Article 156, para 2 of the Federal Constitution). Bills are first considered by one chamber and then, if approved, are passed on to the other. Except in the case of urgency, the second chamber will only consider the bill in a subsequent session of parliament. Considerations in either chamber are organised as a two-step process: bills are first considered by the parliamentary

\footnotetext{
${ }^{24} \mathrm{cfSchweizerische} \mathrm{Bundeskanzlei,} \mathrm{Botschaftsleitfaden:} \mathrm{Leitfaden} \mathrm{zum} \mathrm{Verfassen} \mathrm{von} \mathrm{Botschaften} \mathrm{des} \mathrm{Bundesrates,}$ 4th edn (Bern, 2019), available online (in German, French and Italian) at: www.bk.admin.ch > Dokumentation > Sprachen > Hilfsmittel für Textredaktion und Übersetzung > Leitfaden für Botschaften des Bundesrates.

${ }^{25}$ The Federal Gazette is available online (in German, French and Italian) at: www.admin.ch > Bundesrecht > Bundesblatt.

${ }^{26}$ As the text enacted by Parliament may deviate from the text described in the dispatches (see section 30.2.3), the courts may also consult the official bulletin protocolling the parliamentary deliberations, available online at: www.parlament.ch > Parliamentary business $>$ Official bulletin.
} 
committee in charge, which makes a recommendation, and only then by the chamber as a whole. The committee as well as any Member of Parliament may propose amendments to a bill, and either chamber may amend the bill, refer it back to the Federal Council or to the committee entrusted with its examination for review or amendment, refuse to introduce the bill in the first place or, after consideration, reject it altogether. Due to the Swiss Parliament's relative independence from the executive ( $c f$ section 30.1 .3 ), this is not a rare occurrence.

If, following consideration of a bill, there are differences between the chambers, the divergent decisions of each chamber are referred to the other chamber for consideration until agreement is reached between the two chambers. If there are still differences following three detailed discussions in each chamber, a conciliation committee composed of select members of both chambers is appointed; this committee is tasked with proposing a compromise motion that eliminates the remaining differences in their entirety. If the compromise motion is rejected by either of the chambers, the bill is abandoned.

\subsubsection{Referendum, Commencement and Publication}

Constitutional amendments are subject to a mandatory referendum and federal acts are subject to an optional referendum ( $c f$ section 30.1.2). Constitutional amendments generally come into force on the day of their adoption by the people and the cantons (Article 15, para 3 of the Political Rights Act), whereas the commencement of federal acts is usually delegated to the Federal Council.

Ordinarily, enactments must be published at least five days before they come into force (Article 7, para 1 of the Publications Act) ${ }^{27}$ Swiss federal law is published in two ways: in a chronological compilation, ${ }^{28}$ where the texts are published in the form in which they are enacted, and in a systematic compilation, ${ }^{29}$ where they are presented in consolidated form. If in doubt, the version of a text published in the chronological compilation is authoritative; until 2015, this referred to the paper version of the texts, but since January 2016, the electronic version published on the website of the Confederation has become authoritative (Article 15 of the Publications Act). ${ }^{30}$

\subsubsection{Evaluation}

Article 170 of the Swiss Federal Constitution stipulates that: 'The Federal Assembly shall ensure that federal measures are evaluated with regard to their effectiveness.' While this provision is often mentioned in discussions of how Swiss legislation is evaluated ex post, its practical impact is moderate at best. It may act as a reminder for Parliament to take seriously its duty to aim for 'good' legislation, but it cannot be enforced by the Supreme Court due to Article 190 of the Federal Constitution ( $c f$ section 30.1.3).

\footnotetext{
${ }^{27}$ Publications Act of 18 June 2004 (SR 170.512).

${ }^{28}$ Available online at: www.admin.ch $>$ Bundesrecht $>$ Amtliche Sammlung.

${ }^{29}$ Available online at: www.admin.ch $>$ Bundesrecht $>$ Systematische Rechtssammlung.

${ }^{30} c f$ Federal Council Dispatch of 28 August 2013 on the amendment of the Publications Act (BBl 2013 7057), available online at: www.admin.ch/opc/de/federal-gazette/2013/7057.pdf.
} 
This circumstance may also explain why, so far, more recent trends in ex ante evaluation have not been applied on a regular basis in Switzerland. While the dispatch or report accompanying a bill must include a cursory assessment of its potential effects and costs (Article 141 of the Parliament Act; $c f$ section 30.2.2.3), an in-depth ex-ante evaluation is not required. However, calls for such an evaluation (eg, regulatory impact assessment) or a limitation on legislative activity (eg sunset legislation or one-in, one-out legislation) to be installed in the legislative process have become more frequent in recent years. ${ }^{31}$

\subsection{Techniques}

Switzerland's constitutional set-up has also influenced its drafting techniques. Two elements in particular stand out: (a) the multi-lingualism of its legal system; and (b) Switzerland's tradition of plain-language drafting. The latter has recently come under threat from (c) international and particularly EU law.

\subsubsection{Multi-lingualism}

Switzerland has four national languages (German, French, Italian and Romansh), the first three of which serve as official languages of the Confederation (Articles 4 and 70, para 1 of the Federal Constitution). All federal legislation is published in German, French and Italian, and 'the three versions are equally binding' (Article 14, para 1 of the Publications Act). ${ }^{32}$

Federal acts (and constitutional amendments brought about by way of legislation) may originally be drafted either in German or in French, but for the first round of internal review at the latest, drafts are made available in both languages (co-revision). ${ }^{33}$ For the sake of reviewing drafts of federal acts, the Internal Drafting Committee forms working groups for four, consisting of a linguist and a lawyer of either language. The two versions of the text are revised and further developed in parallel. At the end of this process, neither language version can be considered the 'original' or the 'translation' anymore. Due to the relatively small number of Italian-speaking civil servants, the Italian version of a federal act, even though equally binding, is a mere translation of the German and the French texts. Prior to the final vote in Parliament, a special parliamentary committee, the Drafting Committee of the Federal Assembly, ${ }^{34}$ ensures, among other things, 'that the versions in the three official languages are consistent' (Article 57, para 2 of the Parliament Act), ie, that all three language versions have the same form and the same content. In contrast to federal acts, ordinances except for the most important ordinances - are usually drafted in just one language and are

\footnotetext{
${ }^{31} c f$ F Uhlmann, 'Politische Vorstösse für bessere Gesetze: Eine Auslegeordnung und eine vorsichtige Bewertung' in D Canapa, R Landolt and N Müller (eds), Sein und Schein von Gesetzgebung: Erwartungen - Auswirkungen Kritik (Zurich, Dike, 2018) 4-10.

${ }^{32}$ Publications Act of 18 June 2004 (SR 170.512).

${ }^{33} \mathrm{cf}$ Höfler et al (n 17) 160.

${ }^{34}$ cf S Steiner, 'Redaktionskommission' in M Graf, C Theler and M von Wyss (eds), Parlamentsrecht und Parlamentspraxis der Schweizerischen Bundesversammlung (Basel, Helbing Lichtenhahn, 2014) 465-89.
} 
only translated into the other languages towards the end of the drafting process; the Federal Chancellery ensures that the three language versions are consistent (co-editing). ${ }^{35}$

Popular initiatives, in most cases, are originally submitted in just one language. The text is then translated and co-revised by the administration; this happens in close coordination with the initiators. At the end of this process, the administration certifies that the three language versions of the text are equivalent. After this point, the text can no longer be changed and the collection of the required signatures may begin. ${ }^{36}$

The multi-lingualism of the Swiss legal system represents both a challenge and an opportunity. On the one hand, additional safeguards have to be put in place to ensure that all language versions of a legislative text end up having the same content. This requires extra time and the involvement of additional language experts. On the other hand, comparing different language versions of a legislative text has proven useful both for legislative drafting, where uncertainties and loopholes may be found that would otherwise have been overlooked, and for the later interpretation of the text by the courts, where ambiguities present in one language version may be resolved when consulting the others. ${ }^{37}$ However, this advantage builds on the fact that the number of language versions to be considered is small and that even though there are multiple languages, there is only one legal system.

\subsubsection{Plain Language}

Switzerland has a long-standing tradition of plain-language legislative drafting that dates back at least to the beginnings of the modern Swiss state in the late nineteenth and early twentieth centuries, ${ }^{38}$ and continues to play an important part in Switzerland's public, political and legal discourse. ${ }^{39}$ There are several explanations for this tradition. ${ }^{40} \mathrm{~A}$ first explanation may be found in the instruments of participation and direct democracy provided by the Swiss Constitution. The fact that the public will be invited to comment on the draft of a new piece of legislation and the possibility that the people will have to vote on it create strong incentives for the use of plain language: the more sceptical people are of the comprehensibility of an act, the less likely they are to accept it. A second explanation is closely related: Switzerland's so-called 'militia' tradition. Customarily, a majority of the public offices in Switzerland have been held not by career politicians or lawyers, but by laymen. Among other things, this has also had an effect on the language of Swiss laws: in comparison to

\footnotetext{
${ }^{35} c f$ Höfler et al (n 17) 161.

${ }^{36}$ All popular initiatives, past and present, can be inspected online at: www.bk.admin.ch > Politische Rechte > Volksinitiativen.

${ }^{37}$ cf A Lötscher, 'Multilingual Law Drafting in Switzerland' in G Grewendorf and M Rathert (eds), Formal Linguistics and Law (Berlin, De Gruyter, 2009) 371-400; R Bratschi and M Nussbaumer, 'Mehrsprachige Gesetzgebung' in E Felder and F Vogel, Handbuch Sprache im Recht (Berlin, De Gruyter, 2017), 367-90; F Uhlmann and S Höfler, 'Multilingual Legislative Drafting in Swiss Cantons: Burden or Blessing?' (2018) 1 The Loophole - Journal of the Commonwealth Association of Legislative Counsel 54.

${ }^{38}$ The tradition is closely linked with Eugen Huber, the author of the Swiss Civil Code of 10 December 1907 (SR 210), who in his introductory notes to the bill set out principles of plain-language drafting that have been applied until today (available online at: www.eugenhuber.ch $>$ Texte $>$ Einleitung).

${ }^{39} \mathrm{cf}$ A Griffel (ed), Vom Wert einer guten Gesetzgebung (Bern, Stämpfli, 2014).

${ }^{40} \mathrm{cf}$ M Nussbaumer, 'Die deutsche Gesetzessprache in der Schweiz' in M Brambilla, J Gerdes and C Messina (eds), Diatopische Variation in der deutschen Rechtssprache (Berlin, Frank \& Timme, 2014) 134.
} 
Germany's legislative language, which is generally considered to be complex, difficult to understand and almost pedantically detail-oriented, Switzerland's legislative language seems plain, down to earth and easily accessible. ${ }^{41}$ A third explanation for Switzerland's tradition of plain-language drafting can be found in the aforementioned multi-lingualism of its legal system: Swiss laws have to be rendered in multiple languages and this is easier to accomplish if they are written in plain language.

At the federal level of government, the use of plain language has even been enshrined in the law: Article 7, paragraph 1 of the Languages Act ${ }^{42}$ stipulates that the federal authorities must 'endeavour to ensure that their language is appropriate, clear and comprehensible and shall ensure that gender-appropriate wording is used. Moreover, the care for plainlanguage legislative drafting has been entrusted to a special institution, the Internal Drafting Committee of the Federal Administration, an institution whose main purpose is to ensure that all federal enactments are drafted in comprehensible language. The Committee is composed of language specialists as well as legal experts; it checks all drafts of federal acts and ordinances in the course of the internal review process and provides the authors with suggestions as to how their draft could be improved from a linguistic point of view. Even though the Committee has no authority over the text, it has become well established in Switzerland's legislative process since its creation in $1976^{43}$ and its advice is generally respected and followed. This is particularly due to the fact that the Committee does not just criticise drafts, but actually suggests alternative wordings where a text is difficult to understand. The authors in turn are obliged to discuss the Committee's suggestions and it is often in the course of this personal exchange that an adequate final wording is found. ${ }^{44}$

Drafts of federal acts are additionally examined by a special parliamentary committee, the Drafting Committee of the Federal Assembly, prior to the final vote in Parliament. ${ }^{45}$ This committee is also tasked, among other things, with ensuring that the texts are formulated in a concise and understandable manner' (Article 57, para 2 of the Parliament Act). However, due to the late point at which it comes into play, its influence on the texts is much more limited than that of the adminstration's Internal Drafting Committee.

\subsubsection{International Law}

With regard to the relationship between national and international law, Switzerland has adopted a monist system. ${ }^{46}$ International law does not have to be translated into national law; rather, it is incorporated into Swiss law as is once it has been ratified and thus becomes directly applicable. ${ }^{47}$ However, international treaties frequently have to be implemented by

\footnotetext{
${ }^{41}$ U Karpen, 'Schweizerische Rechtsetzung und Rechtsetzungslehre - ein Blick von aussen' [2012] Zeitschrift für Gesetzgebung 68.

${ }^{42}$ Languages Act of 5 October 2007 (SR 441.1).

${ }^{43}$ cf M Nussbaumer, '1976-2016: 40 Jahre VIRK - 40 Jahre GTR - 40 Jahre Arbeit an der guten Gestalt von Erlassen des Bundes' (2016) 1 LeGes 118.

${ }^{44} c f$ Nussbaumer (n 20); Höfler (n 20); Höfler et al (n 17) $57 f$.

${ }^{45}$ Steiner (n 34).

${ }^{46} \mathrm{cf}$ Misic and Töpperwien (n 1) 50.

${ }^{47}$ The international law applicable in Switzerland can be inspected online (in German, Frenchn and Italian) at: www.admin.ch > Bundesrecht $>$ Systematische Sammlung des Bundesrechts (SR) > Internationales Recht.
} 
means of national legislation. For this purpose, legal concepts and legal terminology alien to Swiss law have to be transposed into national legislation.

The challenge is particularly accentuated with regard to European Union (EU) law. While Switzerland is not a member of the EU, its law has nevertheless become closely intertwined with EU law. This development leads to a clash of two legislative cultures that in many regards could not be more different: on one side, Switzerland's tradition of plainlanguage, no-nonsense drafting, and on the other, the EU's habit of composing verbose, detail-oriented legislative texts. In general, there are three possible strategies to implement EU law in Swiss legislation: the EU provision can be either copied, rephrased or merely referenced in the Swiss text. Copying has the advantage that it creates the appearance that the EU and the Swiss provision are identical. It also does not require the authors of the Swiss text to fully understand the EU provision. However, this strategy often raises the problem that the original provision is taken out of context and thus in fact does not retain its original meaning when inserted in the Swiss text. Rephrasing, in turn, often has the advantage that it facilitates the understandability of the text and that the provision better fits into the context of the Swiss law. However, it comes with the disadvantages that it is labour-intensive and that one can never be sure whether the rephrased provision has exactly the same meaning as the EU provision. Finally, referencing is cheap and makes it transparent that the respective provision originates from and is meant to be identical to EU legislation. The problem is that it often obfuscates the actual content of a provision: the content only becomes clear once one has studied the respective EU text and followed any further references contained therein. ${ }^{48}$ In sum, none of the mentioned solutions is ideal. Thus, the influence of EU legislation will likely continue to pose a threat to Switzerland's tradition of plain-language and high-transparency drafting.

\subsection{Education}

Legal education in Switzerland, like elsewhere, is still almost exclusively concerned with the interpretation and application of law; traditionally, the education of lawyers has included very little training in the theory and practice of legislation. ${ }^{49}$ Recently, however, some Swiss universities have begun to offer such courses at the master's level: master's courses in legislation can now be attended at the Universities of Basel, Bern, Fribourg, Geneva and Zurich. ${ }^{50}$ These recent developments notwithstanding, drafting skills are still mostly acquired on the job, eg, with the help of guidelines for legislative drafting. ${ }^{51}$

\footnotetext{
${ }^{48}$ cf Schweizerische Bundeskanzlei, Faustregeln für die Umsetzung von EU-Recht in schweizerisches Recht (Bern, 2017), available online (in German, Frenchn and Italian) at: www.bk.admin.ch > Dokumentation > Rechtsetzungsbegleitung > Übernahme von EU-Recht: Formale Aspekte > Hilfsmittel.

${ }^{49}$ cf M Wyss, 'Legistische Aus- und Weiterbildung in der Schweiz: Angebote, Akteure, Perspektiven' in F Uhlmann and S Höfler (eds), Professional Legislative Drafters: Status, Roles, Education (Zurich, Dike, 2016) 7-13; F Uhlmann, 'Developments in the Education of Legislation and Regulation: Germany and Switzerland' in HR Shouten (ed), De opleiding van wetgevingsjuristen en wetgevingsonderzoekers in rechtsvergelijkend perspectief (Nijmegen, Wolf, 2011) 43-60.

${ }^{50}$ Uhlmann (n 49) 51.

${ }^{51}$ cf Bundesamt für Justiz, Gesetzgebungsleitfaden: Leitfaden für die Ausarbeitung von Erlassen des Bundes, 4th edn (Bern, 2019), available online (in German, Frenchn and Italian) at: www.bj.admin.ch > Staat \& Bürger > Legistik > Legistische Hauptinstrumente; Schweizerische Bundeskanzlei (n 21).
} 
Several institutions offer vocational training for practitioners. The Institute of Federalism of the University of Fribourg, together with the Swiss Society of Legislation, the Swiss Federal Chancellery and the Federal Office of Justice, organise two seminars on legal methodology and legal drafting every year (the so-called 'Murten Seminars'). The Centre d'étude, de technique et d'évaluation législatives (CETEL) of the University of Geneva regularly offers similar courses in French. The Swiss Society of Legislation and the Centre for Legislative Studies at the University of Zurich each organise annual conferences and seminars.

Since 1990, the Swiss Society of Legislation, together with the Swiss Evaluation Society, has edited a scientific journal dedicated to legislation: LeGes - Legislation \& Evaluation. ${ }^{52}$ LeGes appears three times a year. It includes theoretical and applied papers in German, French, Italian, Romansh and English that deal with questions relating to the goal of achieving good, comprehensible and effective legislation. LeGes serves as a channel of communication for the practitioners and scholars of legislation in Switzerland.

\subsection{Outlook}

In comparison to other countries, the legislative process in Switzerland is relatively slow. This has to do with its federalism, direct democracy and separation of powers. It might be asked whether the 'engine' powering Swiss legislation is too weak and its 'breaks' too strong to meet the expectations of a swift implementation of internationally accepted standards. However, the slowness of the Swiss legislative process, combined with its tendency to search for compromise before any decisions have been taken, has proven to yield good results. Despite frequent complaints that the quality of legislation has markedly decreased and that better regulation is urgently needed, ${ }^{53}$ Switzerland on average still produces 'good' laws: both its legislative process and the actual texts that the process yields exhibit relatively high levels of transparency and are generally well accepted. However, this achievement has come under pressure from an increasingly activist political environment, the growing influence of ever more complex international and EU law, and the fast pace at which legislation is expected to happen in an age where digitalisation has become an end in itself. ${ }^{54}$ Only time will tell whether Switzerland can maintain the quality of its legislation in such political, legal and societal circumstances.

\section{Further Reading}

P Egli, Introduction to Swiss Constitutional Law (Zurich, Dike, 2016)

A Flückiger, (Re)faire la loi (Bern, Stämpfli, 2019)

A Griffel (ed), Vom Wert einer guten Gesetzgebung (Bern, Stämpfli, 2014)

W Haller, The Swiss Constitution in a Comparative Context (Zurich, Dike, 2016)

\footnotetext{
${ }^{52}$ The journal is available free of charge online at: www.leges.ch.

${ }^{53}$ cf Griffel (n 39).

${ }^{54}$ cf A Huber-Hotz, 'Mit Sprache einen Staat machen' in A Lötscher and M Nussbaumer (eds), Denken wie ein Philosoph und schreiben wie ein Bauer (Zurich, Schulthess, 2007) 1-3.
} 
A Lötscher and M Nussbaumer (eds), Denken wie ein Philosoph und schreiben wie ein Bauer: Sprache, mit der ein Staat zu machen ist (Zurich, Schulthess, 2007)

A Misic and N Töpperwien, Constitutional Law in Switzerland, 2nd edn (Bern, Stämpfli, 2018)

G Müller and F Uhlmann, Elemente einer Rechtssetzungslehre, 3rd edn (Zurich, Schulthess, 2013)

RJ Schweizer and M Borghi (eds), Mehrsprachige Gesetzgebung in der Schweiz - Législation plurilingue en Suisse - Legislazione purilingue in Svizzera - La legislaziun plurilingua en Svizra (Zurich, Dike, 2011)

M Thommen (ed), Introduction to Swiss Law (Bern, Carl Grossmann, 2018) 